\title{
Antigenic characterization of Enteromyxum leei (Myxozoa: Myxosporea)
}

\author{
Itziar Estensoro*, Pilar Álvarez-Pellitero, Ariadna Sitjà-Bobadilla \\ Instituto de Acuicultura Torre de la Sal, Consejo Superior de Investigaciones Científicas (IATS-CSIC), Torre de la Sal s/n, \\ 12595 Ribera de Cabanes, Castellón, Spain
}

\begin{abstract}
Enteromyxum leei, an intestinal myxozoan parasite affecting a wide range of fish, was partially purified, and the immunogenic composition of its glycoproteins as well as the proteolytic activity were studied. Parasite extracts, mainly containing spores, were separated by SDSPAGE, and thereafter, immunoblots were carried out with a polyclonal antiserum (Pab) raised against E. leei. Periodic acid/Schiff staining of gels, periodate- and Proteinase K-treated Western blots and Lectin blots were performed to analyse the terminal carbohydrate composition of the parasite's antigens. Additionally, the cross-reaction of the parasite extracts with a Pab raised against the polar filament of the myxozoan Myxobolus pendula was studied. Both Pabs detected proteic epitopes on antigenic proteins and glycoproteins of E. leei, ranging between 15 and $280 \mathrm{kDa}$. In particular, 2 glycoproteic bands (15 and $165 \mathrm{kDa})$, immunoreactive to both Pabs and with glucose and mannose moieties, could correspond to common antigens shared among myxozoans. The $165 \mathrm{kDa}$ band also presented galactose, $\mathrm{N}$-acetyl-galactosamine and $\mathrm{N}$-acetyl-glucosamine, pointing to its possible origin on chitin-built spore valves and to its possible involvement in host-parasite interactions. The molecular weight of the $15 \mathrm{kDa}$ glycoproteic antigen matches that of minicollagen, a cnidarian-specific protein of nematocysts with a myxozoan homologue. Several proteases with apparent molecular weights ranging between 43 and $245 \mathrm{kDa}$ were found in zymographies of $E$. leei extracts, and these may have a potential role in the parasite's pathogenesis. This is a useful approach for further studies to detect targets for antiparasitic therapy.
\end{abstract}

KEY WORDS: Western blot · Polyclonal antibody $\cdot$ Glycoprotein $\cdot$ Lectin $\cdot$ Protease $\cdot$ Parasite

\section{INTRODUCTION}

Intensively cultured fish are susceptible to parasitic infections, a primary concern for the aquaculture sector (Mennerat et al. 2010). Among fish parasites, the members of the myxozoan genus Enteromyxum infect intestines, mainly of marine fish. They cause severe enteritis that results in weight loss, poor feed conversion, delayed growth and even death (Rigos \& Katharios 2010, Sitjà-Bobadilla \& Palenzuela 2012). E. leei affects a wide range of hosts (Sitjà-Bobadilla \& Palenzuela 2012), including gilthead sea bream (GSB) Sparus aurata, the most important marine finfish in Mediterranean aquaculture (APROMAR
2012). In this sparid, E. leei provokes a chronic intestinal infection with epithelial destruction and intense inflammatory reaction leading to emaciation, anemia and mortalities (Fleurance et al. 2008, Sitjà-Bobadilla et al. 2008, Estensoro et al. 2011).

Little is known about the antigen composition of this parasite, and this is a key aspect for the understanding of parasite infectivity and survival in the host. No efficacious treatments are available for enteromyxoses (Bermúdez et al. 2006, Golomazou et al. 2006, Yokoyama \& Shirakashi 2007), and thus it is important to identify potential targets for the development of chemotherapeutants and vaccines. Previous lectin histochemistry studies have shown that the 
different Enteromyxum leei stages have different surface-associated carbohydrate moieties (Redondo \& Álvarez-Pellitero 2009). Such terminal sugar residues are believed to play a paramount role in hostparasite interactions and may form a protective sheath for the parasites that helps them to evade host recognition (Hicks et al. 2000, Theodoropoulos et al. 2001). Therefore, some parasites, such as Trypanosoma cruzi (Buscaglia et al. 2006), employ an antigen variation strategy through modification of $\mathrm{N}$ - and $\mathrm{O}$ glycosides of glycoepitopes in their surface glycoproteins (Gagneux \& Varki 1999, Knaus \& El-Matbouli 2005). In fish, as in all vertebrates, the lectin pathway of the complement system is an ancient first line defense mechanism of the innate immune system that relies on recognition of pathogen-associated glycan epitopes (Sunyer \& Lambris 1998, Nakao et al. 2006, Kania et al. 2010). In previous studies, the glycoproteins of some piscine parasites have been studied by lectin blotting (Feng \& Woo 1998b, Kim et al. 1999, Muñoz et al. 2000a, Knaus \& El-Matbouli 2005).

Another approach to studying the antigenicity of myxozoans is the use of polyclonal antibodies (Pabs) (Bartholomew et al. 1989, Saulnier \& deKinkelin 1996, Muñoz et al. 1999b, 2000a, Lu et al. 2002, Knaus \& ElMatbouli 2005, Zhang et al. 2010). In the present study, the antigenic glycoproteins of Enteromyxum leei were analysed using 2 Pabs; one raised against $E$. leei and another raised against the polar filament of Myxobolus pendula (Ringuette et al. 2011). The latter Pab was chosen to check its possible crossreaction with $E$. leei antigens and for its proven capacity to detect common myxosporean and other cnidarian antigens.

Parasitic invasion mechanisms imply penetration and colonization of host tissues. Proteolytic enzymes generated by parasites are often involved in such processes, as studied for the myxozoans Kudoa sp. (Martone et al. 1999, Funk et al. 2008), Myxobolus cerebralis (Kelley et al. 2004, Dörfler \& El-Matbouli 2007) and Sphaerospora dicentrarchi (Muñoz et al. 2000a), as well as for other piscine parasites (Zuo \& Woo 1998, Paramá et al. 2004, Piazzón et al. 2011). There is no current knowledge about the mechanisms that Enteromyxum leei employs to disrupt cell junctions between enterocytes, to penetrate and invade the intestinal epithelium and to migrate along the digestive tract. Parasite-derived proteinases may play an important role in pathogenesis as well as in lesion formation and evasion of the host immune response in enteromyxosis due to E. leei, and thus they may represent targets for antiparasitic chemotherapy (McKerrow et al. 1993).
The antigenic characterization of Enteromyxum leei is an issue of great importance with little available information. Here we probed the reactivity of $E$. leei antigens with a set of lectins to determine its terminal carbohydrate composition, and with 2 different antibodies. Additionally, the proteolytic activity of E. leei antigen preparations was determined. Such information may help to develop further studies aiming to select parasite antigens with immunopreventive potential against enteromyxosis.

\section{MATERIALS AND METHODS}

\section{Fish and parasite extracts}

Parasite-free and clinically healthy GSB from a commercial fish farm were kept in $5 \mu \mathrm{m}$ filtered and UV irradiated sea water at temperatures always above $18^{\circ} \mathrm{C}$. Some fish were used as control (C) and others as recipient fish (R) for Enteromyxum leei experimental infections (see Sitjà-Bobadilla et al. 2007, Estensoro et al. 2010). All efforts were made to minimize suffering of the fish used for the experiments in accordance with national (Royal Decree RD1201/2005, for the protection of animals used in scientific experiments) and current European Union legislation on handling experimental animals.

$\mathrm{C}$ and $\mathrm{R}$ fish were starved for $2 \mathrm{~d}$, euthanized by overexposure to MS-222 (Sigma) and bled by caudal puncture to avoid sample contamination by blood cells. Infective status of $\mathrm{R}$ intestines was checked by light microscopy observation of fresh smears. Intestines were opened lengthwise under sterile conditions and the mucosa lightly scraped with a scalpel. The intestinal scrapings of $7 \mathrm{C}$ and 7 intensively infected R fish were pooled separately, homogenized in sterile HBSS (Gibco-Life Technologies) with an antibacterial and antimycotic mixture (10000 units $\mathrm{ml}^{-1}$ of penicillin, $10000 \mu \mathrm{g} \mathrm{ml}^{-1}$ of streptomycin and $25 \mu \mathrm{g} \mathrm{ml}^{-1}$ of Fungizone, ${ }^{\circledR}$ Gibco-Life Technologies) using a syringe, and the remaining cell aggregations and debris were retained by a $40 \mu \mathrm{m}$ cell strainer (BD). The parasite/cell suspensions were then centrifuged at $2200 \times g\left(10 \mathrm{~min}\right.$ at $\left.4^{\circ} \mathrm{C}\right)$ and the pellets resuspended in lysis buffer (Tris- $\mathrm{HCl} 0.1 \mathrm{M}, \mathrm{MgCl}_{2}$ 0.05 M, $1 \%$ Triton X-100, sucrose 0.3 M). Suspensions were then centrifuged at $1100 \times g\left(5 \mathrm{~min}\right.$ at $\left.4^{\circ} \mathrm{C}\right)$ and the pellet resuspended in ether:HBSS (1:2) before a subsequent centrifugation at $2500 \times g(5 \mathrm{~min}$ at $4{ }^{\circ} \mathrm{C}$ ). Antigen pellets from $\mathrm{R}$ pools contained mainly spores and unlysed disporoblasts (about $66 \%$ of the parasite extract) together with some small-sized cel- 
lular debris, and those from $\mathrm{C}$ pools contained intestinal epithelium cellular debris. They were collected separately and washed twice in cold HBSS $(2500 \times g$, 5 min at $4^{\circ} \mathrm{C}$ ).

Parasites contained in antigen preparations were counted with a haemocytometer. The protease inhibitor cocktail cOmplete ULTRA Tablets ( ${ }^{\circledR}$ Roche Diagnostics) was added to the protein extracts. After determining their total protein content via Bradford staining (Bio-Rad), the extracts were aliquoted and stored at $-20^{\circ} \mathrm{C}$ until used. The parasite extracts obtained from $\mathrm{R}$ fish also contained host cells because complete parasite purification was not achieved. Therefore, all subsequent analyses aimed to detect parasite bands present in $\mathrm{R}$ intestinal extracts that were absent in $\mathrm{C}$ intestinal extracts.

\section{SDS-PAGE}

$\mathrm{C}$ and $\mathrm{R}$ antigen preparations were boiled for $5 \mathrm{~min}$ and then an equal volume of reducing SDS-PAGE sample buffer $(0.62$ Tris- $\mathrm{HCl}, 2 \% \mathrm{SDS}, 10 \%$ glycerol, $0.005 \%$ bromophenol blue, 0.1 M DTT) was added. They were boiled again for $5 \mathrm{~min}$, centrifuged $\left(13000 \times g\right.$, $30 \mathrm{~min}$ at $\left.4^{\circ} \mathrm{C}\right)$, and the supernatants containing the soluble protein fraction were recovered and stored at $-20^{\circ} \mathrm{C}$ until used. For the preparation of native antigens, extracts were not denatured by boiling, and non-reducing sample buffer lacking DTT was used. Thereafter, antigen preparations were separated by SDS-PAGE either on $12 \%$ or $5 \%$ polyacrylamide gels at $180 \mathrm{~V}$ for approximately $50 \mathrm{~min}$. Gels were used either to visualize proteic antigen bands (Coomassie staining), to visualize glycoproteic antigen bands (Periodic acid/Schiff staining, PAS) or used for further blotting. In all gels, prestained broad range molecular weight (MW) standards (Bio-Rad; $7-209 \mathrm{kDa}$ ) were loaded.

For protein staining, $0.25 \%$ Coomassie brilliant blue R-250 (IBF Pharmindustrie Rèactifs) in 40\% methanol, $10 \%$ acetic acid was employed, followed by washing with $40 \%$ methanol, $10 \%$ acetic acid. For PAS staining, gels were fixed in $25 \%$ isopropyl alcohol, $10 \%$ acetic acid overnight; then in $10 \%$ isopropyl alcohol, $10 \%$ acetic acid for $2 \mathrm{~h} ; 0.5 \%$ periodic acid for $2 \mathrm{~h} ; 0.5 \%$ sodium arsenate, $5 \%$ acetic acid for 40 min i $0.1 \%$ sodium arsenate, $5 \%$ acetic acid for $20 \mathrm{~min}$, twice; and acetic acid for $20 \mathrm{~min}$. Gels were then stained with Schiff's reagent overnight and washed with $0.1 \%$ sodium metabisulphite in $0.01 \mathrm{~N}$ $\mathrm{HCl}$ several times until the rinse solution was no longer coloured pink.

\section{Polyclonal antibodies}

The production and characterization of the Pab raised against Enteromyxum leei (PabEleei) is described in a previous work (Estensoro et al. 2013). This antiserum was adsorbed with normal GSB intestinal scrapings to avoid background noise due to host cell detection. The adsorbed PabEleei (aPabEleei) was used in Western blots for the current antigenic study.

Before blotting, the Pab against the polar filament of Myxobolus pendula (PabMPPF) was checked for cross-reactivity with Enteromyxum leei on paraffin histological sections of infected GSB intestines. Routine immunohistochemical procedures were applied as described by Estensoro et al. (2012) and sections eventually counterstained with Gill's haematoxylin, dehydrated and mounted in di-N-butyl-phthalate in xylene (DPX). PabMPPF was obtained and kindly provided by Ringuette et al. (2011) and is directed against an evolutionary conserved glycoepitope of polar filaments detected in 3 Myxobolus species as well as in some cnidarian nematocysts.

\section{Western blots}

The antigen proteins separated by SDS-PAGE were transferred to a nitrocellulose membrane $(0.45 \mu \mathrm{m}$ pore size; Bio-Rad) at $250 \mathrm{~mA}$ for $1 \mathrm{~h}$. Membranes were blocked with $5 \%$ skimmed milk (Merck) in TBS (20 mM Tris- $\mathrm{HCl}, 0.5 \mathrm{M} \mathrm{NaCl}, \mathrm{pH} 7.2$ ) overnight at $4^{\circ} \mathrm{C}$ and washed $10 \mathrm{~min}$ with TTBS $(0.05 \%$ Tween 20 in TBS). All washing procedures consisted of successive 10 min immersions in TTBS, and all washing and incubation steps were performed at room temperature (RT) with gentle shaking. After washing, membranes were incubated for $2 \mathrm{~h}$ either with Pabs or with biotinylated lectins and washed again 4 times. Detailed information about the used Pabs and lectins can be found in Table 1. Secondary incubations for Western blots were performed with goat anti-rabbit horseradish peroxidase-conjugated antibody 1 :2000; Sigma) and for lectin blots with avidin-biotin-peroxidase complex (VECTOR Laboratories) for a further $2 \mathrm{~h}$. Blots were washed 4 times and finally rinsed in TBS before bound peroxidase was visualized by addition of 3,3'-diaminobenzidine tetrahydrochloride chromogen (DAB; Sigma) for $2 \mathrm{~min}$. The reaction was stopped with deionised water and blots were allowed to dry. Reactive antigen bands in gels and blots were visualized with a Multi-Image light cabinet (Alpha Innotech Corporation) and digitally analysed with Quantity-One Quantitation Software (Bio- 
Table 1. Detector molecules used in Western blots. Ab: antibody; GalNac: N-acetylgalactosamine; Gal: galactose; Glc: Dglucose; GlcNAc: N-acetylglucosamine; Man: mannose; NeuNAc: N-acetylneuraminic acid; Fuc: Fucose; IATS: Instituto de Acuicultura Torre de la Sal

\begin{tabular}{|c|c|c|c|c|}
\hline Detector molecule (antibody or lectin) & Abbreviation & Binding specificity & Dilution used & Source \\
\hline Rabbit polyclonal Ab anti-Enteromyxum leei & aPabEleei $^{\mathrm{a}}$ & Unknown & $1: 500$ & IATS \\
\hline Rabbit polyclonal Ab anti-polar filament & PabMPPF $^{b}$ & $\begin{array}{l}\text { Non-collagenous glycoprotein } \\
\text { of Myxobolus pendula }\end{array}$ & $1: 30$ & $\begin{array}{l}\text { University of } \\
\text { Toronto }\end{array}$ \\
\hline Canavalia ensiformis-Agglutinin & ConA & Man $\alpha-1>$ Glc $\alpha-1>$ GlcAc $\alpha-1$ & $2 \mu \mathrm{g} \mathrm{ml} \mathrm{l}^{-1}$ & Sigma \\
\hline Bandeiraea simplicifolia-Lectin & BSL I & D-Gal > D-GalNac & $5 \mu \mathrm{g} \mathrm{ml} \mathrm{g}^{-1}$ & Sigma \\
\hline Glycine max-Agglutinin & SBA & Terminal $\alpha, \beta$ GalNac $>\alpha, \beta$ Gal & $5 \mu \mathrm{g} \mathrm{ml} \mathrm{m}^{-1}$ & Vector Lab. \\
\hline Triticum vulgaris-Agglutinin & WGA & $\begin{array}{c}\text { GlcNAc }(\beta 1,4 \text { GlcNAc })_{1-2}> \\
\beta 1,4 \text { GlcNAc }>\text { NeuNAc }\end{array}$ & $10 \mu \mathrm{g} \mathrm{ml}^{-1}$ & Vector Lab. \\
\hline Sambucus nigra-Agglutinin & SNA & $\begin{array}{c}\text { NeuAc- } \alpha 2,6 \mathrm{Gal}= \\
\text { NeuAc } 22,6 \mathrm{GalNAc}\end{array}$ & $20 \mu \mathrm{g} \mathrm{ml}^{-1}$ & Vector Lab. \\
\hline Ulex europaeus-Agglutinin & UEA & L-Fuc $\alpha 1,2 \mathrm{Gal} \beta 1,4$ & $20 \mu \mathrm{g} \mathrm{ml}^{-1}$ & Sigma \\
\hline
\end{tabular}

Rad). Band sizes were inferred from the linear range of the migration of MW standards.

\section{Periodate oxidation}

Periodate oxidation was carried out as described by Woodward et al. (1985) to demonstrate the carbohydrate nature of the epitopes recognized by the Pabs. Following the blotting, membranes were rinsed with $0.05 \mathrm{M}$ sodium acetate buffer ( $\mathrm{pH} 4.5)$ and incubated for $1 \mathrm{~h}$ in the dark at RT with graded periodate dilutions $(0.1 \mathrm{mM} ; 1 \mathrm{mM} ; 10 \mathrm{mM})$ in sodium acetate buffer. Blots were then rinsed with sodium acetate buffer, incubated with $0.05 \mathrm{M}$ sodium borohydride in phosphate-buffered saline for $30 \mathrm{~min}$ at RT and washed 5 min with TTBS and 5 min with TBS. Thereafter, membranes were blocked, exposed to the primary and secondary antibodies, exposed to DAB and finally dried and visualized as described in the previous section.

\section{Proteinase K digestion}

Blots were digested with Proteinase $\mathrm{K}$ to confirm the polypeptide nature of the antigen epitopes detected by the Pabs, as described by Feng \& Woo (1998a). Briefly, blotted membrane strips were incubated for $1 \mathrm{~h}$ at $37^{\circ} \mathrm{C}$ with Proteinase K $\left(0.2 \mu \mathrm{g} \mathrm{ml}{ }^{-1}\right.$, $2 \mu \mathrm{g} \mathrm{ml}^{-1}, 20 \mu \mathrm{g} \mathrm{ml}^{-1}$ ) in Tris- $\mathrm{HCl}$ (50 mM, pH 8) and then washed in TTBS and $12 \%$ trichloracetic acid to inactivate the proteinase. Thereafter, membranes were blocked, incubated with the primary and secondary antibodies, exposed to DAB and finally dried and visualized as described in the previous section.

\section{Zymography}

The proteolytic activity of the antigen preparations was tested by separating them through SDS-PAGE in $10 \%$ polyacrylamide gels co-polymerized with $0.2 \%$ gelatine. Cell extracts employed therefore were native and not reduced, thus, not boiled and did not contain DTT in the SDS-PAGE sample buffer. After electrophoresis, gels were washed in $2.5 \%$ Triton X-100 (Sigma) for $1 \mathrm{~h}$ to remove SDS and restore proteolytic activity, rinsed with $0.1 \mathrm{M}$ phosphate buffer ( $\mathrm{pH}$ 5.5) and then incubated with this same buffer for $12 \mathrm{~h}$ at $37^{\circ} \mathrm{C}$ to allow proteolysis. Finally, gels were stained with $0.25 \%$ Coomassie brilliant blue R-250 and visualized with a Multi-Image light cabinet (Alpha Innotech Corporation) as previously described. Proteases appeared as clear bands on the blue background where digestion of co-polymerized gelatine occurred.

\section{RESULTS}

\section{SDS-PAGE: Coomassie and PAS}

The parasite content of $\mathrm{R}$ extracts ranged between $6.1 \times 10^{6}$ and $4.1 \times 10^{7}$ parasite stages $\mathrm{ml}^{-1}$ and their total protein content ranged between 297 and $904 \mathrm{mg} \mathrm{ml}^{-1}$. In Coomassie brilliant blue R-250 
stained gels (Fig. 1, Lanes A-D), denatured and reduced parasite extracts showed $\mathrm{R}$ proteic bands of MWs ranging between 10 and $49 \mathrm{kDa}$. The detected $\mathrm{R}$ antigenic bands were 3 intense bands of low MW $(10,15$ and $17 \mathrm{kDa})$ and 3 weakly stained bands of 30 , 31 and $42 \mathrm{kDa}$, respectively. Except the $42 \mathrm{kDa}$ band, all of these $\mathrm{R}$ bands were absent in C extracts. Native $\mathrm{R}$ extracts presented a similar band pattern with a slightly lower relative mobility (native proteic bands: 11, 16, 18.5, 31, 33 and $49 \mathrm{kDa}$ ).

In PAS-stained gels (Fig. 1, Lanes E,F), C extracts did not show PAS-positive bands, whereas in R parasite extracts, a single high-MW glycoprotein band of $193 \mathrm{kDa}$ was weakly stained. The MW of this glycoproteic band was confirmed in $5 \%$ polyacrylamide gels.

\section{Western blots}

The immunoblots with aPabEleei showed several immunoreactive bands in $\mathrm{R}$ antigen preparations (Fig. 2, Lane B). In reduced and denatured R extracts, aPabEleei detected reactive bands with MWs of 15, 23, 42, 67 and $165 \mathrm{kDa}$ together with an intense smear ranging from 24 to $37 \mathrm{kDa}$. In native $\mathrm{R}$ extracts, aPabEleei detected only 30 and $43 \mathrm{kDa}$ reactive bands as well as a weakly stained $33 \mathrm{kDa}$ reactive band. In $\mathrm{C}$ antigens, this antibody detected only 29 and $42 \mathrm{kDa}$ reactive bands.

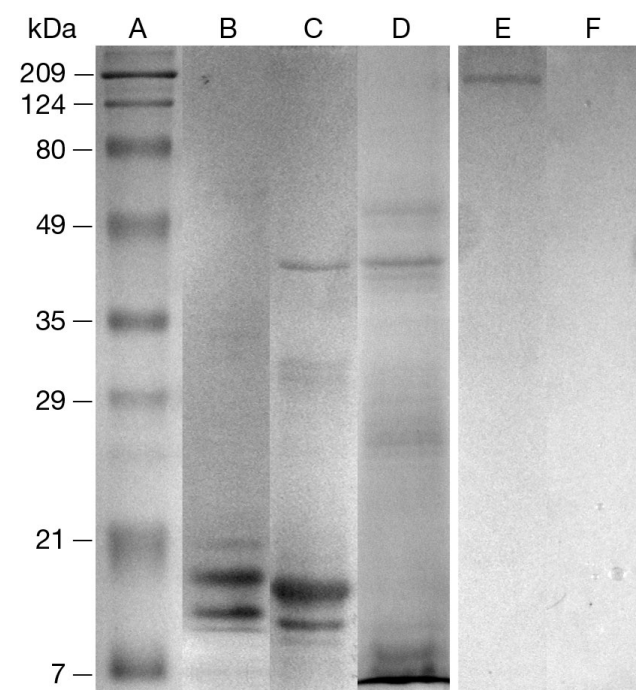

Fig. 1. SDS-PAGE soluble protein profile of parasite extracts of Enteromyxum leei (Lanes B, C, E) and host tissue extracts (Lanes D, F) stained with R-250 Coomassie brilliant blue (Lanes A-D) and PAS (Lanes E-F). Lane A, molecular weight standards; Lane B, native E. leei extract; Lanes C and E, denatured and reduced $E$. leei extract; Lanes D and $F$, denatured and reduced host tissue extracts
The immunoblots with PabMPPF showed reactive antigens between 15 and $>209 \mathrm{kDa}$ in $\mathrm{R}$ reduced and denatured extracts (Fig. 2, Lanes E,F). Reactive bands had MWs of 15, 29, 42, 154 and $166 \mathrm{kDa}$, and a reactive smear of $>209 \mathrm{kDa}$ (mean MW $280 \mathrm{kDa}$ ) was also detected. Only a $42 \mathrm{kDa}$ band was detected in C extracts. Using immunohistochemistry, this PabMPPF clearly stained primary and secondary cells of proliferative parasite stages and polar filaments, polar capsules, spore valves and accompanying cells of sporogonic stages of Enteromyxum leei (Fig. 3). No label was detected either in negative control slides omitting primary antibody, secondary antibody and avidin-biotin-peroxidase complex, respectively, or in non-parasitized tissues. For comparative purposes, an image of the staining obtained with aPabEleei is also provided (Fig. 3).

Terminal sugar moieties of glycoproteic bands were determined with 6 biotinilated plant lectins, which detected a broad array of reactive bands in lectin blots, some of them exclusive of R extracts. The lectin Canavalia ensiformis-Agglutinin (ConA) detected mannose/ glucose (Man/Glc) residues in glycoproteic bands of $15,27,31,33,34,36,39,46,49,165$ and $311 \mathrm{kDa}$, which were all absent in $\mathrm{C}$ extracts (Fig. 4, Lanes $\mathrm{B}, \mathrm{C}$ ). Bandeiraea simplicifolia-Lectin (BSL I) detected galactose/N-acetyl-galactosamine (Gal/GalNac) moieties in 2 exclusive bands of R extracts with MWs of 148 and $165 \mathrm{kDa}$ (Fig. 4, Lanes D,E). Glycine max-

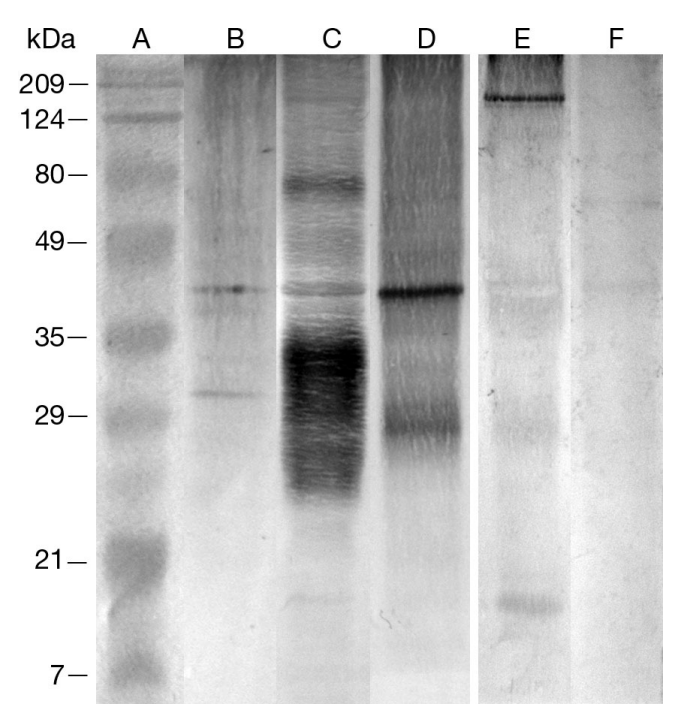

Fig. 2. Western blot detection of Enteromyxum leei (Lanes B, $\mathrm{C}, \mathrm{E}$ ) and host tissue (Lanes D, F) extracts with the polyclonal antibody raised against $E$. leei (Lanes B-D) and by the polyclonal antibody against polar filament epitopes of Myxobolus pendula (Lanes E, F). Lane A is the molecular weight standard 


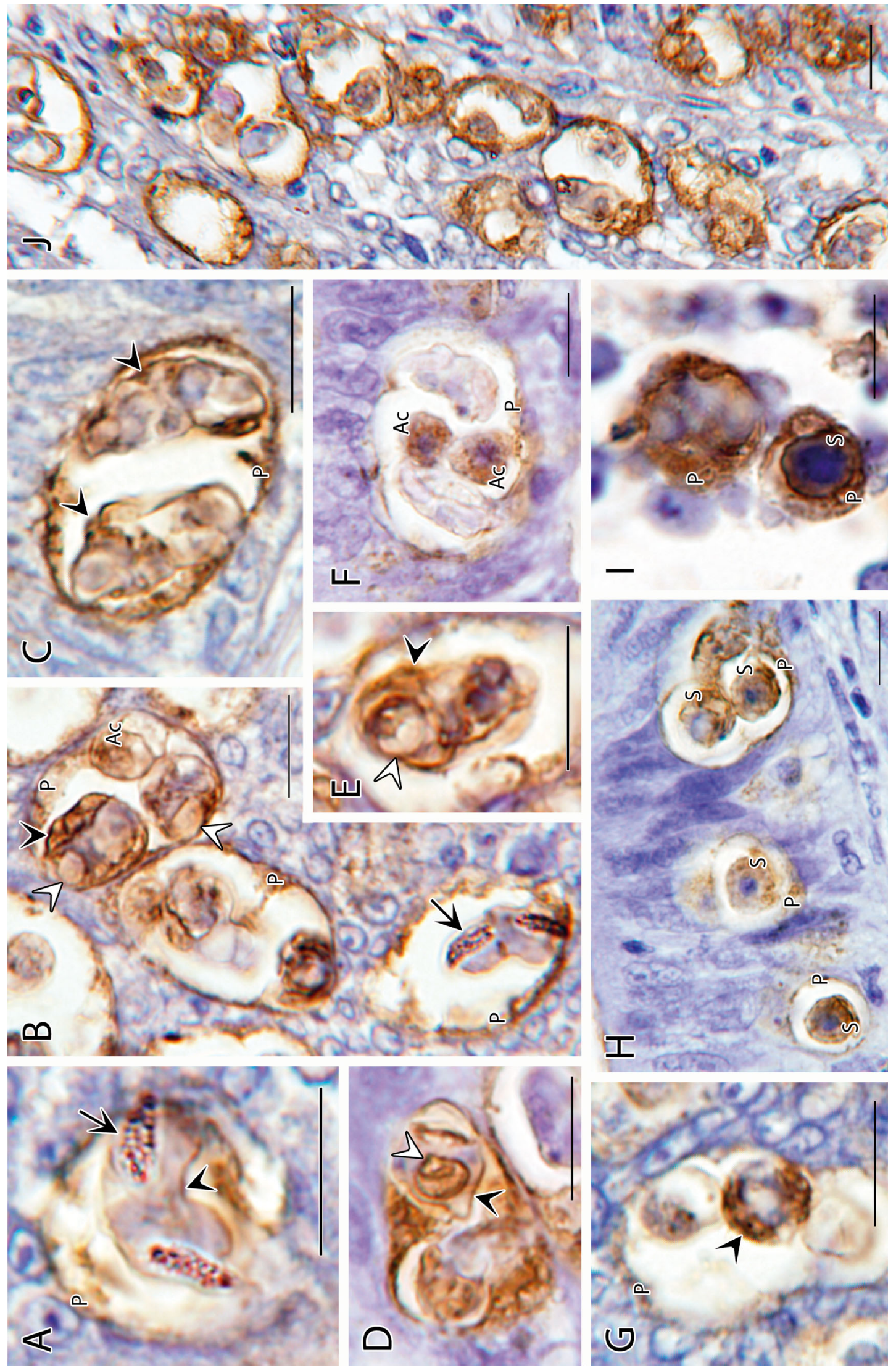

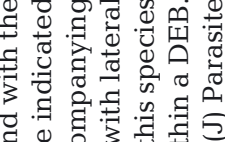
वै.

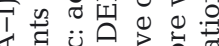
व

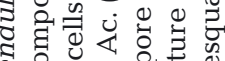
बं 0 त क्ष क्ष

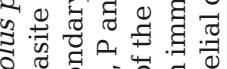
ठํ.

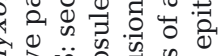

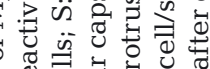

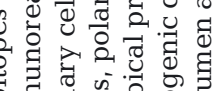
के चี 미릴

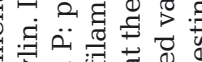

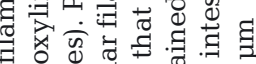
t $\frac{7}{7}$ :

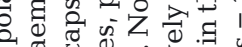

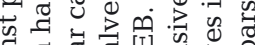

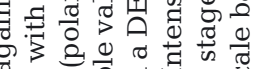
0 u 궁

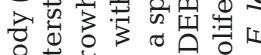

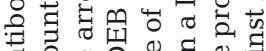

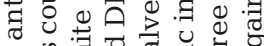

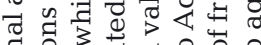
울 政

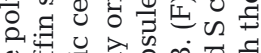

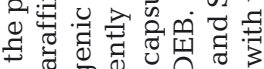

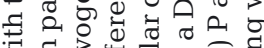

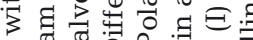
ه

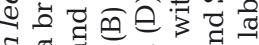
政 0

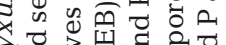

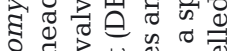

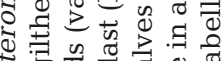

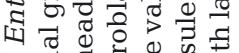

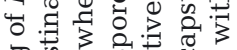
का के

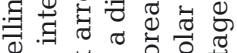

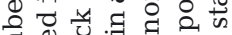

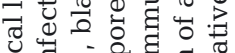

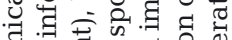
व.

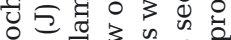

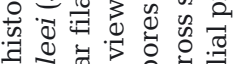

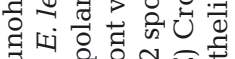

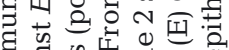
द्व

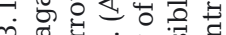
m के vं

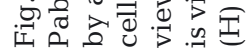


Agglutinin (SBA) reacted with N-acetyl-galactosamine/galactose (GalNac/Gal) residues in 2 highMW bands only present in $\mathrm{R}$ extracts, 164 and $271 \mathrm{kDa}$ (Fig. 4, Lanes F,G). With Triticum vulgarisAgglutinin (WGA), 3 glycoprotein bands of 158, 165 and $239 \mathrm{kDa}$ containing N-acetyl-glucosamine/ neuraminic acid (GlcNac/NeuNac) were visualized exclusively in $\mathrm{R}$ extracts (Fig. 4, Lanes $\mathrm{H}, \mathrm{I}$ ). The $108 \mathrm{kDa}$ reactive band detected with Sambucus
nigra-Agglutinin (SNA) (specific for NeuAc) was found in both $\mathrm{R}$ and $\mathrm{C}$ extracts (Fig. 4, Lanes $\mathrm{J}, \mathrm{K}$ ), and no clear results could be obtained with the Ulex europaeus-Agglutinin (UEA) lectin (specific for fucose) due to the high background noise.

The optic density profiles obtained for reduced and denatured R extracts blotted with aPabEleei, PabMPPF and ConA are represented in Fig. A1 in Appendix 1.

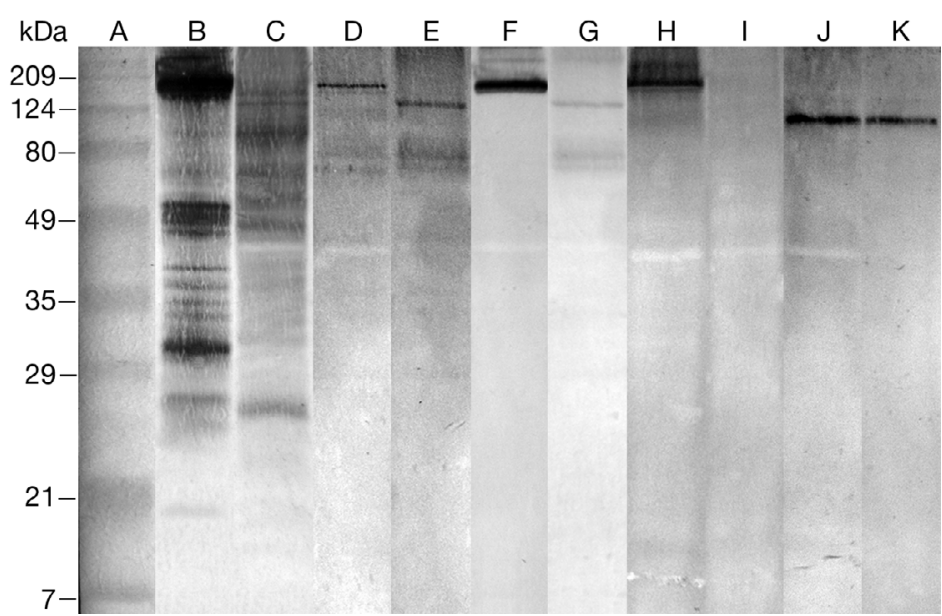

Fig. 4. Lectin blot detection of Enteromyxum leei (Lanes $B, D, F, H, J)$ and host tissue (Lanes $\mathrm{C}, \mathrm{E}, \mathrm{G}, \mathrm{I}, \mathrm{K}$ ) extracts with the biotinylated plant lectins ConA (Lanes B,C), BSL I (Lanes D,E), SBA (Lanes F,G), WGA (Lanes $\mathrm{H}, \mathrm{I}$ ) and SNA (Lanes $\mathrm{J}, \mathrm{K})$. Lane A is the molecular weight standard

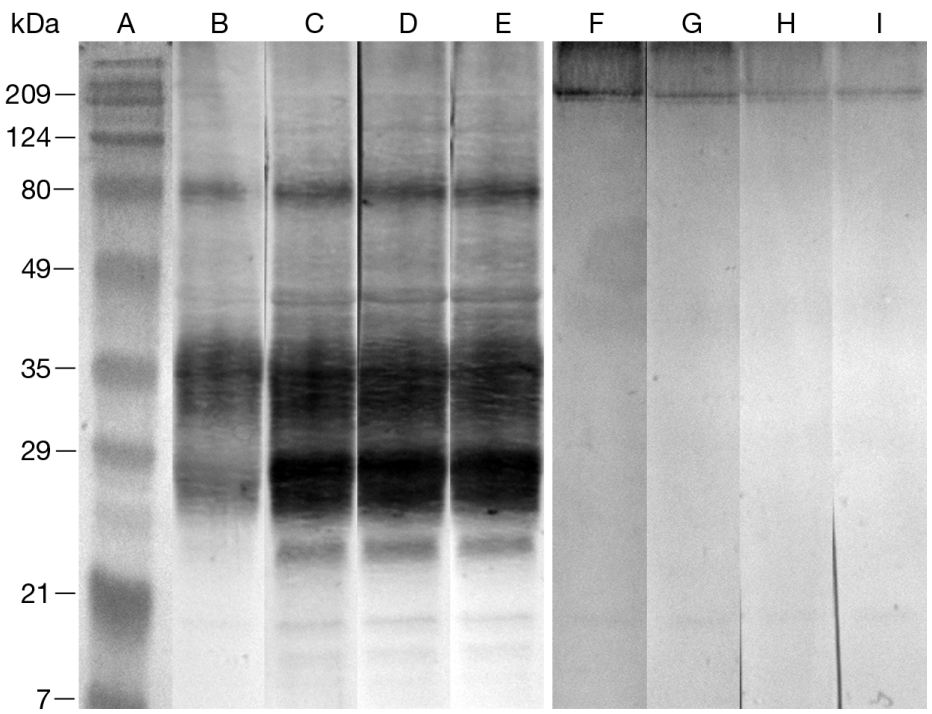

Fig. 5. Western blot reactivity of Enteromyxum leei parasite extract with the polyclonal antibody against $E$. leei (Lanes B-E) and with the polyclonal antibody against Myxobolus pendula polar filament (Lanes F-I) after sodium periodate oxidation (Lanes B and F, 0 mM; Lanes C and $\mathrm{G}_{1} 0.1 \mathrm{mM}$; Lanes D and $\mathrm{H}, 1 \mathrm{mM}$; Lanes E and I, $10 \mathrm{mM}$ ). Lane A is the molecular weight standard

\section{Periodate oxidation}

Following the treatment with sodium periodate, no reduction in the number of reactive bands recognized by aPabEleei was observed (Fig. 5, Lanes B-E). Similarly, the immunoreactive bands detected by the PabMPPF did not decrease after the sodium periodate treatment (Fig. 5, Lanes F-I). Band detection with both Pabs was maintained at the different periodate concentrations used.

\section{Proteinase $\mathrm{K}$ digestion}

The reactivity of $\mathrm{R}$ proteins with aPabEleei in Western blots was reduced after Proteinase $\mathrm{K}$ digestion (Fig. 6, Lanes B-E). A progressive reduction of the antibody's label was observed at increasing Proteinase K concentrations, and the label almost disappeared after incubation with Proteinase $\mathrm{K}$ at $20 \mu \mathrm{g}$ $\mathrm{ml}^{-1}$. Likewise, the intensity of the PabMPPF immunoreactive bands was progressively reduced after incubation with increasing concentrations of Proteinase K, eventually disappearing at $20 \mu \mathrm{g} \mathrm{ml}^{-1}$.

\section{Zymography}

The zymography detected gelatinolytic proteases with a broad MW range, from 27 up to $>209 \mathrm{kDa}$, for $\mathrm{C}$ and R extracts (Fig. 7). Accurate assessment of proteinase molecular mass through zymography was not possible since migration is affected by gelatine inclusion in the gel, and moreover, we used native extracts that had neither been boiled nor reduced (Hummel et al. 1996). In any case, proteolytic bands only present in R extracts had apparent MWs of 43, 49, 113 and $245 \mathrm{kDa}$, together with a smear of a mean MW of $174 \mathrm{kDa}$ and 2 weak bands of 58 and $66 \mathrm{kDa}$ (Fig. 7, Lane B). 


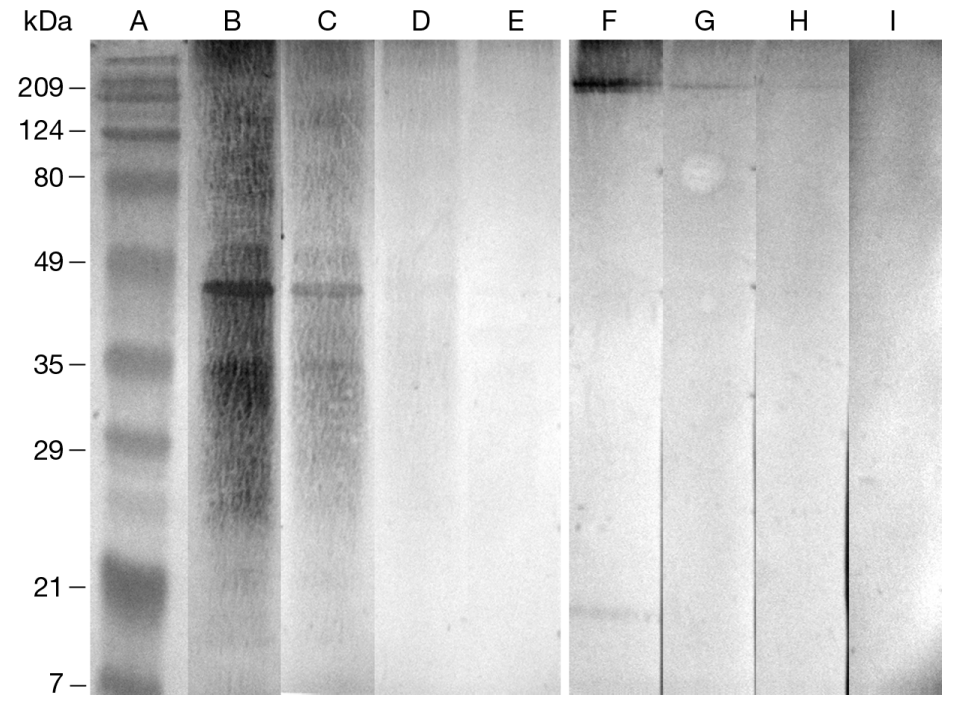

Fig. 6. Western blot reactivity of Enteromyxum leei parasite extract with the polyclonal antibody against E. leei (Lanes B-E) and with the polyclonal antibody against Myxobolus pendula polar filament (Lanes F-I) after Proteinase $\mathrm{K}$ digestion (Lanes $\mathrm{B}$ and $\mathrm{F}, 0 \mathrm{mM}$; Lanes $\mathrm{C}$ and $\mathrm{G}$, $0.2 \mathrm{mM}$; Lanes D and H, $2 \mathrm{mM}$; Lanes $\mathrm{E}$ and I, $20 \mathrm{mM}$ ). Lane $\mathrm{A}$ is the molecular weight standard

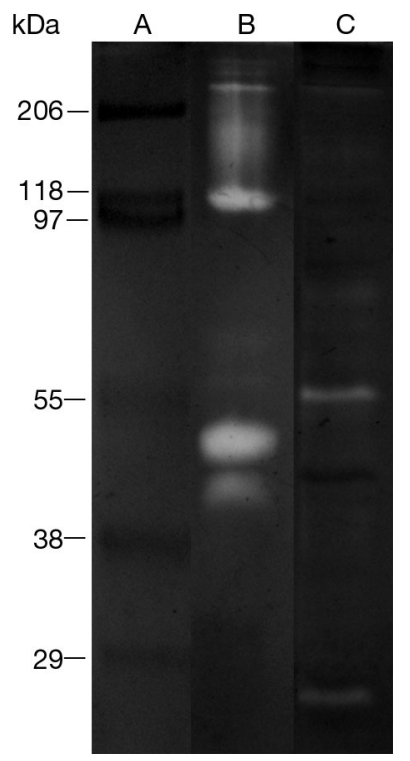

Fig. 7. Protease zymography of Enteromyxum leei (Lane B) and host tissue (Lane C) extracts using gelatine non-reducing SDS-PAGE. Lane $\mathrm{A}$ is the molecular weight standard

\section{DISCUSSION}

The antigenic characterization of Enteromyxum leei, a parasite with economic impact on the aquaculture industry, has been a postponed issue due to its complex purification. In the current study, E. leei antigens were obtained and analysed by several immunological and biochemical techniques leading to their identification and partial characterization.

Large amounts of spores together with some disporous sporoblasts were contained in the $\mathrm{R}$ parasite extracts yielding concentrations of over $6 \times 10^{6}$ parasite stages $\mathrm{ml}^{-1}$. Spores constitute a large proportion of the parasite stages found in well established Enteromyxum leei infections in GSB, either free or as part of sporoblasts. Nevertheless, the specific role of $E$. leei spores in the life cycle of the parasite and its infectivity for the fish host is uncertain (Diamant et al. 2006). However, as described in other myxozoans, the role of myxospores is most likely the transmission to an annelid intermediate host (Yokoyama et al. 2012). Indeed, an actinosporean (Unicapsulactinomyxon type) with an SSU rDNA sequence that is 80 to $84 \%$ related to Enteromyxum spp. was found in Portugal (Rangel et al. 2011). E. leei spores were demonstrated to be immunogenic for rabbits, as the aPabEleei specifically detected surface epitopes on spore valves by immunohistochemistry (Estensoro et al. 2013). The immunogenicity of myxospores in organisms different than the corresponding hosts (mice and rabbits) has already been observed in other studies (Clouthier et al. 1997, Chase et al. 2001, 2003). Furthermore, the role of myxospores in resistance development in fish has been suggested. In the case of Myxobolus cerebralis, common antigens for actinospores and myxospores were discovered, and the latter generated an antibody response in fish (Morris et al. 2004). In any case, the presence of sporoblasts in the parasite extracts provided antigens from primary and secondary accompanying cells, both of importance for the parasite's pathogenicity because they are infective for fish (Cuadrado et al. 2008). Obtaining a pure E. leei extract was not possible due to its localization inside the intestinal epithelium and its adherence to host enterocytes, but most host-derived cells were eliminated and highly enriched parasite extracts were achieved. In all assays, host background in parasite extracts was identified by comparison with parasite-free $\mathrm{C}$ intestinal extracts. Indeed, a $42 \mathrm{kDa}$ band apparently of piscine origin was detected in all gels and Western blots of R extracts. However, it cannot be discounted that parasite antigens could mimic host antigens to evade immune attack (Bartholomew et al. 1989, Lu et al. 2002, Villavedra et al. 2007).

SDS-PAGE, lectin and Western blotting have proved to be useful techniques for the visualization and char- 
acterization of antigen proteins and glycoconjugates of Enteromyxum leei. Protein profiles in Coomassie brilliant blue stained gels revealed 6 low-MW antigenic bands (10 to $49 \mathrm{kDa}$ ) of parasite origin which differed slightly in their relative migration when separated under native or under reducing denaturalized conditions. Such variation in the speed of migration suggests a non-linear polypeptide structure of the detected antigen proteins, which contain disulphide bonds (Feng \& Woo 1998a). Thus, after the reducing and heating treatment, the unfolded polypeptide presented a higher relative migration.

Further proteic/glycoproteic bands, which were not visualized with Coomassie brilliant blue staining, were detected by Western blotting. Numerous examples exist in the literature in which antibodies or lectins detect additional proteic or glycoproteic bands in blotted membranes that were previously undetected in the Coomassie brilliant blue stained gels (Schumacher \& Krause 1995, Heimann et al. 1997, Newlands et al. 1999, Muñoz et al. 2000a, Tanaka et al. 2007). The reason is the limited sensitivity of the Coomassie staining to detect trace proteins in antigen preparations, in contrast with the high sensitivity of antibodies and lectins. aPabEleei detected 5 different Enteromyxum leei antigens in reduced and denatured cell extracts. All of them had proteic antigen determinants because they were not affected by the periodate oxidation, but by Proteinase K digestion. The detection of fewer bands in native extracts suggests that aPabEleei does not detect conformational epitopes, but rather unfolded polypeptide epitopes, some of them only exposed after reducing and denaturalizing. Although aPabEleei showed specificity for proteic epitopes, some of these bands corresponded to glycosylated proteins also detected by lectins (Table 2; Appendix 1). This was the case of the $34 \mathrm{kDa}$ band positive for Man/Glc sugar moieties (ConA), which coincided with the reactive smear to aPabEleei. Intense smears in Western blotting are characteristic of heavily glycosylated molecules (Chase et al. 2001, Villavedra et al. 2007), in accordance with the observed aPabEleei smear coinciding with a ConA reactive band. The $15 \mathrm{kDa}$ protein was detected by both Pabs and was also positive for Man/Glc. Moreover, the $165 \mathrm{kDa}( \pm 1 \mathrm{kDa})$ aPabEleei-positive proteic band immunoreacted with ConA, BSL I, SBA and WGA, indicating the presence of Man/Glc, Gal, GalNac and GlcNac terminals. The affinity of Pabs for proteic epitopes of parasites has been reported, while Mabs more frequently recognize carbohydrate epitopes (Bartholomew et al. 1989, Clouthier et al. 1997, Chase et al. 2001, Villavedra et al. 2010), which are the predominant surface molecules. Accordingly, the present aPabEleei exclusively recognized peptidic antigens, which are thought to be generally more potent immunogens than glycans and are probably the common epitopes shared between parasites (Villavedra et al. 2007).

Parasite surface glycoconjugates contribute to protecting the parasite from harsh environments and enable host-parasite interactions. Important events among such interactions are recognition and adhesion leading to penetration of the parasite, but also trapping of the parasite by host mucins leading to its removal. Although not all glycopeptids present in our extracts are surface molecules, some could have a role in such interactions. The detected glycoproteic antigens of 15, 34 and $165 \mathrm{kDa}$ of Enteromyxum leei contained Man/Glc moieties, which were the most abundant monosaccharides among the parasite's antigens, compared to the other monosaccharides tested. This result agrees with the ConA staining of E. leei proliferative and sporogonic stages observed by light and electron microscopy (Redondo \& ÁlvarezPellitero 2009) and is a common trait among myxozoans (Muñoz et al. 1999a, 2000b, Morris \& Adams 2004, Kaltner et al. 2007, Redondo et al. 2008). In fact, Man/Glc moieties were present at the host-parasite interface in enteromyxoses (Redondo et al. 2008, Redondo \& Álvarez-Pellitero 2009). The presence of surface Man moieties on offending microorganisms can trigger an innate immune response via complement system by the lectin pathway or via phagocytosis by Man-binding receptors on macrophages (Kaltner et al. 2007). In fact, it is known that complement through the alternative pathway and macrophages through the respiratory burst activity are involved in

Table 2. Enteromyxum leei antigens immunoreactive to the adsorbed polyclonal antibody (Pab) against E. leei (aPabEleei), which were detected by other probes and techniques $\pm 1 \mathrm{kDa}$ difference. Coomassie: Coomassie brilliant blue stain; PabMPPF: Pab against Myxobolus pendula polar filament epitopes; ConA: Canavalia ensiformis-Agglutinin; BSL I: Bandeiraea simplicifolia-Lectin; SBA: Glycine max-Agglutinin; WGA: Triticum vulgaris-Agglutinin

\begin{tabular}{|lccc|}
\hline & \multicolumn{4}{c|}{ E. leei } & \multicolumn{4}{c|}{ antigens } & molecular weight in $\mathrm{kDa})$ \\
& 15 & 34 & 165 \\
\hline Coomassie & + & - & - \\
PabMPPF & + & - & + \\
ConA & + & + & + \\
BSL I & - & - & + \\
SBA & - & - & + \\
WGA & - & - & + \\
Gelatinolytic activity & - & - & + \\
\hline
\end{tabular}


the innate immune response against Enteromyxum spp. (Cuesta et al. 2006, Sitjà-Bobadilla et al. 2006, Estensoro et al. 2011). Furthermore, down-regulation of GSB mannose binding lectin 2 during enteromyxosis was considered as parasite-induced immunodepression (Davey et al. 2011).

In addition to the Man/Glc, the $165 \mathrm{kDa}$ glycoproteic antigen also presented reactivity for WGA, which binds to GlcNac with high affinity. The presence of chitin, a polymer of D-GlcNac, in polar capsules positive for WGA has been described for some myxozoans (Lukes et al. 1993, Muñoz et al. 1999a, 2000b, Kaltner et al. 2007). Myxospore valves also contain substantial amounts of chitin (Lukes et al. 1993, Muñoz et al. 1999a). Thus, bacterial chitinases degrading spore valves of the myxozoan Thelohanellus kitauei have been suggested as alternative biological agents to control myxozoan diseases (Liu et al. 2011). Interestingly, polar capsules of Enteromyxum leei were negative for WGA while other spore structures were positive and putatively contained chitin, as was also the case with the spores of the congener E. scophthalmi (Redondo et al. 2008, Redondo \& Álvarez-Pellitero 2009). Since these authors detected no GlcNac in proliferative stages of $E$. leei, we can hypothesize that the high-MW glycoprotein of $165 \mathrm{kDa}$ is located in spores, and could have a structural, protective function as described for chitin in polar capsule walls. In accordance with this, the $165 \mathrm{kDa}$ glycoproteic band of E. leei was also labelled by BSL I and SBA, both of them only binding to spores of E. leei in light microscopy preparations (Redondo \& Álvarez-Pellitero 2009). These lectins recognize Gal and GalNac carbohydrate residues, which are frequently involved in host-parasite interactions and have also been detected in spores of several myxozoans (Muñoz et al. 1999a, 2000b, Kaltner et al. 2007, Redondo et al. 2008) and in antigenic bands of Myxobolus cerebralis (Knaus \& El-Matbouli 2005). The 165 kDa carbohydrate-rich antigen was not detected by PAS staining, but primary cells, secondary cells and polar capsules of E. leei were PAS positive in histological sections (Álvarez-Pellitero et al. 2008). However, the lack of expected PAS-positive bands has been reported before, due to the higher sensitivity of lectins in Western blotting over PAS staining in SDS-PAGE gels (Wilkinson \& Hames 1983, Schumacher \& Krause 1995).

SNA, specifically binding NeuAc, did not recognize any antigenic band exclusive of Enteromyxum leei. The intense $108 \mathrm{kDa}$ band observed in $\mathrm{R}$ and in $\mathrm{C}$ blots apparently belongs to the host in accordance with the absence of NeuAc residues previously reported for E. leei and E. scophthalmi by immunohistochemistry (Redondo et al. 2008, Redondo \& Álvarez-Pellitero 2009) as well as for Myxobolus cerebralis by lectin blot (Kaltner et al. 2007). However, surface exposed sialic acids may play a role in self/non-self recognition, and therefore some parasites would acquire sialic acid moieties from the host by trans-sialidases as a biological mask to evade immune detection by phagocytes or complement (Feng \& Woo 1998b, Kaltner et al. 2007). Therefore, this band might be alternatively interpreted as a sialylated glycoconjugate of the parasite. Nevertheless, even without sialic acids, E. leei seems to evade the initial immune response of GSB, suggesting the involvement of other glycans in the parasite's masking.

PabMPPF cross-reacted with Enteromyxum leei epitopes on polar filaments, polar capsules, spore valves, and primary and secondary cells. This antibody is directed against a spinalin-like noncollagenous glycoprotein present in Myxobolus pendula cyst extracts which is resistant to cyanogen bromide digestion. Spinalin is a nematocyst-specific, resistant protein tolerating high mechanical stress and with partial homology to avian keratins. Spinalin presented an MW of $24 \mathrm{kDa}$ in Western blot and was localized in stylets, spines and opercula of cnidarian nematocysts (Koch et al. 1998). Immunoreactive spore structures of E. leei to PabMPPF putatively present the spinalin-like peptides which confer a high mechanical strength, but whose function in the primary, secondary and accompanying cells of E. leei is yet to be revealed. The current results show that PabMPPF cross-reacts with several peptidic epitopes of $E$. leei, 2 of which are glycoproteins also detected by aPabEleei (Table 2). In addition, $M$. pendula blotted with PabMPPF presented a $35 \mathrm{kDa}$ antigenic band (Ringuette et al. 2011) almost coinciding with the $34 \mathrm{kDa}$ glycoproteic band detected in the current study by aPabEleei and ConA. Common antigenic determinants shared between E. leei and Sphaerospora spp. have been detected with the aPabEleei, but Myxobolus spp. have not been tested for cross-reactivity (Estensoro et al. 2013). The glycoproteic antigens found in the present study $(15,34$ and $165 \mathrm{kDa})$ (Appendix 1) may represent further common antigens shared between E. leei and other myxosporeans. Such common myxozoan epitopes have been found previously for other species (Muñoz et al. 1998, 1999a,b). In support of the phylogenetic affinity between Cnidaria and Myxozoa, Ringuette et al. (2011) also found cross-reactivity of the PabMPPF in polar filament epitopes of $M$. pseudokoi, $M$. bartai, the anthozoan Nematostella vectensis and the hydrozoan $\mathrm{Hy}$ - 
dra vulgaris and, in the current study, we demonstrated cross-reactivity with E. leei and E. scophthalmi (not shown). Recently, phylogenomic analyses of new genomic sequences of $M$. cerebralis firmly placed Myxozoa as a sister group to Medusozoa within Cnidaria (Nesnidal et al. 2013). Interestingly, minicollagens are phylum-specific genes encoding cnidarian nematocyst proteins, and a minicollagen homologue was discovered in the malacosporean Tetracapsuloides bryosalmonae involving a further link between Myxozoa and Cnidaria (Holland et al. 2011). The inner wall of Hydra magnipapillata nematocyst capsules consists of fibril bundles formed by polymers of small 12 to $15 \mathrm{kDa}$ minicollagens (Koch et al. 1998), coinciding in MW with the $15 \mathrm{kDa}$ glycoproteic band of E. leei recognized by PabMPPF, aPabEleei and ConA. However, at the moment we can only speculate about the existence of a $15 \mathrm{kDa}$ minicollagen monomer in Enteromyxum, and further investigation is required to confirm the nature of this band.

Enteromyxum leei proteases are probably the key to the pathogenesis of enteromyxosis. Different proteases at different stages of the parasite's life cycle are released to degrade host proteins, contributing to invasion, parasite proliferation and tissue damage (McKerrow et al. 1993). Our results showed several functional parasite proteases in E. leei parasite extracts (not detected in $\mathrm{C}$ intestinal extracts). Their in vivo functions may be involved in intra- and extracellular digestion of nutrients and/or destruction of immune relevant host molecules. The release of $E$. leei stages directly to the gut and hence to the environment might depend on epithelial disruption by proteolysis. This release, though causing intestinal tissue damage, might be considered less harmful than the damage caused by other myxozoan species that need to induce host death to be discharged from the host. In the myxozoan Kudoa rosenbushi-infected muscle of Merlucius hubbsi, a protease allows spores to enter muscle fibres and to use the breakdown products as a major nutrient source for the parasite (Martone et al. 1999), and in Oncorhynchus mykiss exposed to Myxobolus cerebralis, the gene expression of MyxSP1 protease in gills increases significantly after exposure (Kelley et al. 2004). Moreover, resistance of an O. mykiss strain to $M$. cerebralis infection is suggested to derive from a difference in susceptibility to parasite proteases (Dörfler \& El-Matbouli 2007). In any case, further characterization of the detected proteases by their inhibitors and their peptide substrates is still needed to decipher the underlying mechanisms and functions of parasiteinduced proteolysis during enteromyxosis.
In this first approach to the antigenic characterization of Enteromyxum leei, several glycoproteic antigens were detected, one of them possibly derived from myxospores. Nevertheless, further improvement of the parasite purification technique is needed to avoid all possible interference of host cells with binding and detection and to definitively discard host-derived antigens. The function played by each glycoconjugate in the host-parasite interaction as well as the characterization of the individual glycoproteic antigens deserve further investigation. The role played by parasite proteases during intestinal invasion and their importance for virulence and pathogenesis are still to be investigated in depth.

Acknowledgements. The PabMPPF was kindly provided by M. J. Ringuette and S. Desser from the Department of Cell and Systems Biology of the University of Toronto (Canada). This work was funded by MICINN through project AGL2009-13282-C02-01, and by the 'Generalitat Valenciana' (projects PROMETEO 2010/006 and ISIC 2012/003). I.E. received a PhD FPI fellowship.

\section{LITERATURE CITED}

Álvarez-Pellitero P, Palenzuela O, Sitjà-Bobadilla A (2008) Histopathology and cellular response in Enteromyxum leei (Myxozoa) infections of Diplodus puntazzo (Teleostei). Parasitol Int 57:110-120

APROMAR (Asociación Empresarial de Productores de Cultivos Marinos) (2012) La acuicultura marina en españa. Available at www.apromar.es/informes.asp (accessed 20 March 2013)

Bartholomew JL, Rohovec JS, Fryer JL (1989) Development, characterization, and use of monoclonal and polyclonal antibodies against the myxosporean, Ceratomyxa shasta. J Protozool 36:397-401

Bermúdez R, Aleman N, Vigliano F, Vázquez S, Quiroga MI, Nieto JM (2006) Effects of symmetric triazinone (toltrazuril) on developmental stages of Enteromyxum scophthalmi parasitizing turbot (Scophthalmus maximus L.): a light and electron microscopic study. Aquaculture 254: 65-71

Buscaglia CA, Campo VA, Frasch ACC, Di Noia JM (2006) Trypanosoma cruzi surface mucins: host-dependent coat diversity. Nat Rev Microbiol 4:229-236

> Chase JC, Dawson-Coates JA, Haddow JD, Stewart MH and others (2001) Analysis of Kudoa thyrsites (Myxozoa: Myxosporea) spore antigens using monoclonal antibodies. Dis Aquat Org 45:121-129

Chase JC, Booy MH, Dawson-Coates JA, Haddow JD and others (2003) Immunological detection of Kudoa thyrsites spores in muscle tissues of farmed Atlantic salmon, Salmo salar L. J Fish Dis 26:427-431

Clouthier SC, Gunning DJ, Olafson RW, Kay WW (1997) Antigenic characterization of Henneguya salminicola. Mol Biochem Parasitol 90:543-548

> Cuadrado M, Marques A, Diamant A, Sitjà-Bobadilla A and others (2008) Ultrastructure of Enteromyxum leei (Dia- 
mant, Lom \& Dykova, 1994) (Myxozoa), an enteric parasite infecting gilthead sea bream (Sparus aurata) and sharpsnout sea bream (Diplodus puntazzo). J Eukaryot Microbiol 55:178-184

> Cuesta A, Muñoz P, Rodríguez A, Salinas I and others (2006) Gilthead seabream (Sparus aurata L.) innate defence against the parasite Enteromyxum leei (Myxozoa). Parasitology 132:95-104

> Davey GC, Calduch-Giner JA, Houeix B, Talbot A and others (2011) Molecular profiling of the gilthead sea bream (Sparus aurata L.) response to chronic exposure to the myxosporean parasite Enteromyxum leei. Mol Immunol 48:2102-2112

> Diamant A, Ram S, Paperna I (2006) Experimental transmission of Enteromyxum leei to freshwater fish. Dis Aquat Org 72:171-178

> Dörfler C, El-Matbouli M (2007) Isolation of a subtilisin-like serine protease gene (MyxSubtSP) from spores of Myxobolus cerebralis, the causative agent of whirling disease. Dis Aquat Org 73:245-251

Estensoro I, Redondo MJ, Álvarez-Pellitero P, SitjàBobadilla A (2010) Novel horizontal transmission route for Enteromyxum leei (Myxozoa) by anal intubation of gilthead sea bream Sparus aurata. Dis Aquat Org 92: 51-58

- Estensoro I, Benedito-Palos L, Palenzuela O, Kaushik S, Sitjà-Bobadilla A, Pérez-Sánchez J (2011) The nutritional background of the host alters the disease course in a fishmyxosporean system. Vet Parasitol 175:141-150

Estensoro I, Calduch-Giner JA, Kaushik S, Pérez-Sánchez J, Sitjà-Bobadilla A (2012) Modulation of the IgM gene expression and the IgM immunoreactive cell distribution by the nutritional background in gilthead sea bream (Sparus aurata) challenged with Enteromyxum leei (Myxozoa). Fish Shellfish Immunol 33:401-410

Estensoro I, Redondo MJ, Álvarez-Pellitero P, Sitjà-Bobadilla A (2013) Immunohistochemical characterization of polyclonal antibodies against Enteromyxum leei and Enteromyxum scophthalmi, intestinal parasites of fish (Myxozoa: Myxosporea). J Fish Dis (in press), doi:10. $1111 /$ jfd.12168

Feng S, Woo PTK (1998a) Characterization of a 200 kDa glycoprotein (Cs-gp200) on the pathogenic piscine haemoflagellate Cryptobia salmositica. Dis Aquat Org 32:41-48

> Feng S, Woo PTK (1998b) Identification of carbohydrates on the surface membrane of pathogenic and nonpathogenic piscine haemoflagellates, Cryptobia salmositica, C. bullocki and C. catostomi (Kinetoplastida). Dis Aquat Org 32:201-209

> Fleurance R, Sauvegrain C, Marques A, Le Breton A, Guereaud C, Cherel Y, Wyers M (2008) Histopathological changes caused by Enteromyxum leei infection in farmed sea bream Sparus aurata. Dis Aquat Org 79: 219-228

> Funk VA, Olafson RW, Raap M, Smith D and others (2008) Identification, characterization and deduced amino acid sequence of the dominant protease from Kudoa paniformis and $K$. thyrsites: a unique cytoplasmic cysteine protease. Comp Biochem Physiol B Biochem Mol Biol 149:477-489

> Gagneux P, Varki A (1999) Evolutionary considerations in relating oligosaccharide diversity to biological function. Glycobiology 9:747-755

Golomazou E, Athanassopoulou F, Karagouni E, Vagianou S, Tsantilas H, Karamanis D (2006) Efficacy and toxicity of orally administrated anti-coccidial drug treatment on Enteromyxum leei infections in sharpsnout seabream (Diplodus puntazzo C.). Isr J Aquacult Bamidgeh 58: 157-169

Heimann K, Becker B, Harnisch H, Mukherjee KD, Melkonian M (1997) Biochemical characterization of plasma membrane vesicles of Cyanophora paradoxa. Bot Acta 110:401-410

Hicks SJ, Theodoropoulos G, Carrington SD, Corfield AP (2000) The role of mucins in host-parasite interactions. Part I - Protozoan parasites. Parasitol Today 16:476-481

Holland JW, Okamura B, Hartikainen H, Secombes CJ (2011) A novel minicollagen gene links cnidarians and myxozoans. Proc R Soc Lond B Biol Sci 278:546-553

> Hummel KM, Penheiter AR, Gathman AC, Lilly WW (1996) Anomalous estimation of protease molecular weights using gelatin-containing SDS-PAGE. Anal Biochem 233: 140-142

Kaltner H, Stippl M, Knaus M, El-Matbouli M (2007) Characterization of glycans in the developmental stages of Myxobolus cerebralis (Myxozoa), the causative agent of whirling disease. J Fish Dis 30:637-647

> Kania PW, Sorensen RR, Koch C, Brandt J and others (2010) Evolutionary conservation of mannan-binding lectin (MBL) in bony fish: identification, characterization and expression analysis of three bona fide collectin homologues of $\mathrm{MBL}$ in the rainbow trout (Onchorhynchus mykiss). Fish Shellfish Immunol 29:910-920

Kelley GO, Zagmutt-Vergara FJ, Leutenegger CM, Adkison MA, Baxa DV, Hedrick RP (2004) Identification of a serine protease gene expressed by Myxobolus cerebralis during development in rainbow trout Oncorhynchus mykiss. Dis Aquat Org 59:235-248

Kim JH, Ogawa K, Wakabayashi H (1999) Lectin-reactive components of the microsporidian Glugea plecoglossi and their relation to spore phagocytosis by head kidney macrophages of ayu Plecoglossus altivelis. Dis Aquat Org 39:59-63

Knaus M, El-Matbouli M (2005) Lectin blot studies on proteins of Myxobolus cerebralis, the causative agent of whirling disease. Dis Aquat Org 65:227-235

Koch AW, Holstein TW, Mala C, Kurz E, Engel J, David CN (1998) Spinalin, a new glycine- and histidine-rich protein in spines of Hydra nematocysts. J Cell Sci 111:1545-1554

> Liu Y, Zhou Z, Miao W, Zhang Y and others (2011) A chitinase from Aeromonas veronii CD3 with the potential to control myxozoan disease. PLoS ONE 6:e29091

> Lu YS, Li M, Wu YS, Wang JG (2002) Antigenic study of Myxobolus rotundus (Myxozoa: Myxosporea) using monoclonal antibodies. J Fish Dis 25:307-310

Lukes J, Volf P, Lom J (1993) Detection of chitin in spores of Myxobolus muelleri and M. subepithelialis (Myxosporea, Myxozoa). Parasitol Res 79:439-440

Martone CB, Spivak E, Busconi L, Folco EJE, Sánchez JJ (1999) A cysteine protease from myxosporean degrades host myofibrils in vitro. Comp Biochem Physiol B Biochem Mol Biol 123:267-272

> McKerrow JH, Sun E, Rosenthal PJ, Bouvier J (1993) The proteases and pathogenicity of parasitic protozoa. Annu Rev Microbiol 47:821-853

> Mennerat A, Nilsen F, Ebert D, Skorping A (2010) Intensive farming: evolutionary implications for parasites and pathogens. Evol Biol 37:59-67

Morris DJ, Adams A (2004) Localization of carbohydrate terminals on Tetracapsuloides bryosalmonae using lectin 
histochemistry and immunogold electron microscopy. J Fish Dis 27:37-45

> Morris DJ, El-Matbouli M, Adams A (2004) Extensive release of an antigen associated with the sporogonic stages of Myxobolus cerebralis (Myxozoa: Myxosporea) is detected by a heterologous antibody raised to Tetracapsuloides bryosalmonae (Myxozoa: Malacosporea). Folia Parasitol 51:215-220

Muñoz P, Sitjà-Bobadilla A, Álvarez-Pellitero P (1998) Immunohistochemical characterization of a polyclonal antibody against Sphaerospora dicentrarchi (Myxosporea: Bivalvulida), a parasite from sea bass (Dicentrarchus labrax L.) (Teleostei: Serranidae). Parasitol Res 84: 733-740

> Muñoz P, Palenzuela O, Álvarez-Pellitero P, Sitjà-Bobadilla A (1999a) Comparative studies on carbohydrates of several myxosporean parasites of fish using lectin histochemical methods. Folia Parasitol 46:241-247

Muñoz P, Palenzuela O, Sitjà-Bobadilla A, Álvarez-Pellitero P (1999b) Immunohistochemical reactivity of polyclonal antibodies against Sphaerospora testicularis and Ceratomyxa labracis (Myxosporea: Bivalvulida), with other myxosporean parasites. Int J Parasitol 29:521-525

Muñoz P, Sitjà-Bobadilla A, Álvarez-Pellitero P (2000a) Antigenic characterization of Sphaerospora dicentrarchi (Myxosporea: Bivalvulida), a parasite from European sea bass Dicentrarchus labrax (Teleostei: Serranidae). Dis Aquat Org 40:117-124

- Muñoz P, Sitjà-Bobadilla A, Álvarez-Pellitero P (2000b) Ultrastructural localisation of carbohydrates in four myxosporean parasites. Parasite 7:185-191

> Nakao M, Kajiya T, Sato Y, Somamoto T and others (2006) Lectin pathway of bony fish complement: identification of two homologs of the mannose-binding lectin associated with MASP2 in the common carp (Cyprinus carpio). J Immunol 177:5471-5479

> Nesnidal MP, Helmkampf M, Bruchhaus I, El-Matbouli M, Hausdorf B (2013) Agent of whirling disease meets orphan worm: phylogenomic analyses firmly place Myxozoa in Cnidaria. PLoS ONE 8:e54576

> Newlands GFJ, Skuce PJ, Knox DP, Smith SK, Smith WD (1999) Cloning and characterization of a $\beta$-galactosidebinding protein (galectin) from the gut of the gastrointestinal nematode parasite Haemonchus contortus. Parasitology 119:483-490

> Paramá A, Iglesias R, Álvarez MF, Leiro J, Ubeira FM, Sanmartin ML (2004) Cysteine proteinase activities in the fish pathogen Philasterides dicentrarchi (Ciliophora: Scuticociliatida). Parasitology 128:541-548

Piazzón C, Lamas J, Leiro JM (2011) Role of scuticociliate proteinases in infection success in turbot, Psetta maxima (L.). Parasite Immunol 33:535-544

> Rangel LF, Cech G, Székely C, Santos MJ (2011) A new actinospore type Unicapsulactinomyxon (Myxozoa), infecting the marine polychaete, Diopatra neapolitana (Polychaeta: Onuphidae) in the Aveiro Estuary (Portugal). Parasitology 138:698-712

> Redondo MJ, Álvarez-Pellitero P (2009) Lectinhistochemical detection of terminal carbohydrate residues in the enteric myxozoan Enteromyxum leei parasitizing gilthead seabream Sparus aurata (Pisces: Teleostei): a study using light and transmission electron microscopy. Folia Parasitol 56:259-267

Redondo MJ, Cortadellas N, Palenzuela O, Álvarez-Pellitero P (2008) Detection of carbohydrate terminals in the enteric parasite Enteromyxum scophthalmi (Myxozoa) and possible interactions with its fish host Psetta maxima. Parasitol Res 102:1257-1267

Rigos G, Katharios P (2010) Pathological obstacles of newlyintroduced fish species in Mediterranean mariculture: a review. Rev Fish Biol Fish 20:47-70

> Ringuette MJ, Koehler A, Desser SS (2011) Shared antigenicity between the polar filaments of myxosporeans and other cnidaria. J Parasitol 97:163-166

Saulnier D, de Kinkelin P (1996) Antigenic and biochemical study of PKX, the myxosporean causative agent of proliferative kidney disease of salmonid fish. Dis Aquat Org 27:103-114

- Schumacher U, Krause WJ (1995) Molecular anatomy of an endodermal gland - investigations on mucus glycoproteins and cell turnover in Brunner's glands of Didelphis virginiana using lectins and PCNA immunoreactivity. J Cell Biochem 58:56-64

Sitjà-Bobadilla A, Palenzuela O (2012) Enteromyxum species. In: Woo PTK, Buchmann K (eds) Fish parasites: pathology and protection. CAB International, Wallingford, p 163-176

> Sitjà-Bobadilla A, Redondo MJ, Bermúdez R, Palenzuela O and others (2006) Innate and adaptive immune responses of turbot, Scophthalmus maximus (L.), following experimental infection with Enteromyxum scophthalmi (Myxosporea: Myxozoa). Fish Shellfish Immunol 21:485-500

> Sitjà-Bobadilla A, Diamant A, Palenzuela O, ÁlvarezPellitero P (2007) Effect of host factors and experimental conditions on the horizontal transmission of Enteromyxum leei (Myxozoa) to gilthead sea bream, Sparus aurata L., and European sea bass, Dicentrarchus labrax (L.). J Fish Dis 30:243-250

Sitjà-Bobadilla A, Calduch-Giner J, Saera-Vila A, Palenzuela O, Álvarez-Pellitero P, Pérez-Sánchez J (2008) Chronic exposure to the parasite Enteromyxum leei (Myxozoa: Myxosporea) modulates the immune response and the expression of growth, redox and immune relevant genes in gilthead sea bream, Sparus aurata L. Fish Shellfish Immunol 24:610-619

Sunyer JO, Lambris JD (1998) Evolution and diversity of the complement system of poikilothermic vertebrates. Immunol Rev 166:39-57

Tanaka AK, Gorin PAJ, Takahashi HK, Straus AH (2007) Role of Leishmania (Leishmania) amazonensis amastigote glycosphingolipids in macrophage infectivity. Braz J Med Biol Res 40:799-806

> Theodoropoulos G, Hicks SJ, Corfield AP, Miller BG, Carrington SD (2001) The role of mucins in host-parasite interactions: Part II - Helminth parasites. Trends Parasitol 17:130-135

> Villavedra M, Lemke S, To J, Broady K, Wallach M, Raison RL (2007) Carbohydrate epitopes are immunodominant at the surface of infectious Neoparamoeba spp. J Fish Dis 30:191-199

> Villavedra M, To J, Lemke S, Birch D and others (2010) Characterisation of an immunodominant, high molecular weight glycoprotein on the surface of infectious Neoparamoeba spp., causative agent of amoebic gill disease (AGD) in Atlantic salmon. Fish Shellfish Immunol 29: 946-955

Wilkinson DG, Hames BD (1983) Characterization of the spore coat proteins of Dictyostelium discoideum. Eur J Biochem 129:637-643

Woodward MP, Young WW, Bloodgood RA (1985) Detection 
of monoclonal-antibodies specific for carbohydrate epitopes using periodate-oxidation. J Immunol Methods 78: 143-153

Yokoyama H, Shirakashi S (2007) Evaluation of hyposalinity treatment on infection with Enteromyxum leei (Myxozoa) using anemonefish Amphiprion spp. as experimental host. Bull Eur Assoc Fish Pathol 27:74-78

Yokoyama H, Grabner D, Shirakashi S (2012) Transmission biology of the Myxozoa. In: Carvalho ED (ed) Health and environment in aquaculture. InTech Publisher online, p 3-42. Available at www.intechopen.com/books/healthand-environment-in-aquaculture/transmission-biologyof-the-myxozoa

Zhang YA, Salinas I, Li J, Parra D and others (2010) IgT, a primitive immunoglobulin class specialized in mucosal immunity. Nat Immunol 11:827-835

Zuo X, Woo PTK (1998) Characterization of purified metalloand cysteine proteases from the pathogenic haemoflagellate Cryptobia salmositica Katz 1951. Parasitol Res 84: 492-498

\section{Appendix}

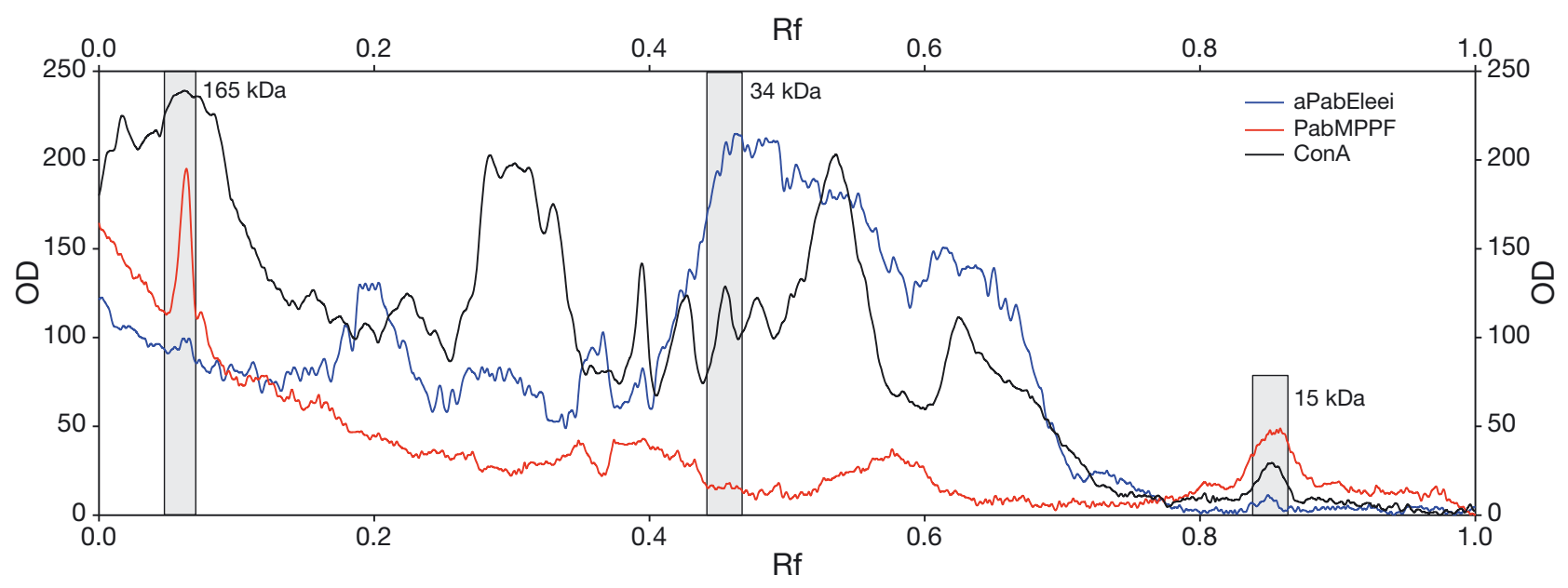

Fig. A1. Optic density (OD) profile along the relative migration distance (Rf) of reduced and denatured Enteromyxum leei extracts in Western blots. Peaks corresponding to the bands of the same molecular weight detected by the polyclonal antibodies against E. leei (aPabEleei) and against Myxobolus pendula polar filament (PabMPPF) and detected by Canavalia ensiformisAgglutinin (ConA) are highlighted by grey shading

Editorial responsibility: Dieter Steinhagen, Hannover, Germany
Submitted: May 6, 2013; Accepted: July 12, 2013

Proofs received from author(s): September 20, 2013 